\title{
"Being en Route": Flight Experiences of Forced Migrants in Austria And Turkey
}

\author{
Denise TaN, Vienna
}

\section{Content}

Abstract.

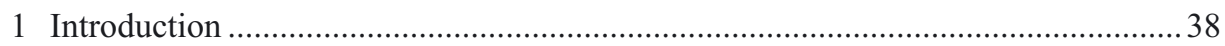

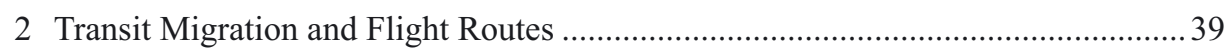

2.1 Theoretical Conceptions of Transit and Forced Migration................................ 40

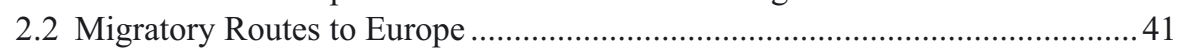

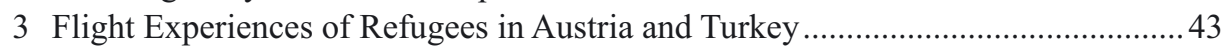

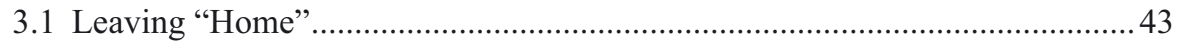

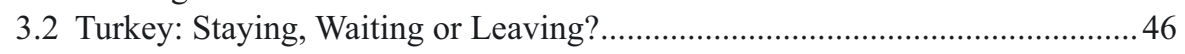

3.3 Smugglers, Networks and the Countries of Destinations ...............................50

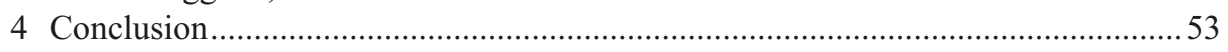

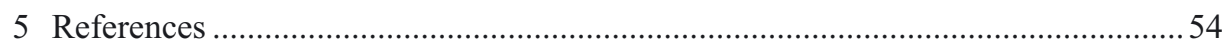

\section{Abstract}

Applying the concept of transit migration from the general field of migration and key insights from forced migration studies, this paper analyses flight experiences from Syrian, Afghan and Iraqi refugees in Austria and Turkey. The flight as such is not a simple linear process, instead forced migrants' routes and plans change en route. The reasons for leaving, the situation of urban refugees in the Turkish transit hub Izmir, as well as the role of smugglers and transnational networks during the flight are examined. Forced migrants arrive in Austria for various reasons, even if they have never intended to do 
so; at the same time a large number of forced migrants are stuck in Turkey struggling to overcome their liminal status.

\section{Introduction}

Photo series, articles and documentaries from news journalists as well as video clips from forced migrants give detailed insights into the means of flight and routes to Europe and the hardships forced migrants experience on their way. Pictures of overloaded rubber boats floating between Turkey and Greece, as well as masses of people crossing the Balkans are especially well known. Some journalists have documented the entire flight routes starting from Turkey or Egypt, for example, Wolfgang Bauer or Serge Daniel (BAUER 2014; DANIEL 2008). Two extraordinary documentaries illustrate flight experiences filmed and narrated by forced migrants themselves, Exodus: Our Journey to Europe (URL1) and My Escape (URL2). Both films were made during the "great wave" of forced migrants in 2015. Refugees from Syria, Afghanistan, Iran, Eritrea and Gambia used their mobile phones to film parts of their flight, starting in their home countries. In a direct and intimate manner the spectator follows the protagonists on trucks and in containers, over the mountains between Iran and Turkey, through the Sahara, on boats across the Mediterranean Sea and through the Balkans to Germany or France. The stories not only show the difficulties and harsh conditions of the flight, but also give insights into the system of smuggling and trafficking. The number of refugees arriving in Austria and Europe during the last few years has preoccupied not only the media but also the social sciences. Quantitative and qualitative research projects, like the pilot study presented in this volume, have been developed across the European Union (URL3; URL4), aiming to study systematically different facets of recent migration movements.

Forced migration and refugee studies offer a broad range of theoretical concepts and explanations to understand and analyse the social phenomena of forced migration (FIDDIAN-QASMIYEH et al.2014). The actual flight, the mobility phase, and the experiences of "being en route" however, have hardly been discussed in research literature. Only a few ethnographic contributions deal with forced migrants' experiences made during the flight or in transit (Conlon 2011; Wissink et al. 2013; Kallius et al. 2016). In 2014, Franck DüVELL and his colleagues brought the concept of "transit migration" into focus, aiming to show its potential usage within the general field of migration (DüvelL et al. 2014). Collyer et al. explain in the introduction to Transit Migration in Europe (2014): "Migration has always been considered as a relatively simple transfer from a country of origin to a country of destination, though this has never been considered unproblematic from the migrants'perspective" (2014, p. 28). This applies especially to forced migrants for whom there are few possibilities to reach Europe legalally. Hence, it is difficult to label individuals 'transit migrants', since the lines between transit migrants and asylum seekers or involuntary migrants are blurred. Transit migration is only loosely defined 
and strongly politicised by scholars and policymakers. CoLLYER et al. argue that the political usage is still widespread and consequently leads to political arguments (2014: 28). Nevertheless, the contributions in that volume demonstrate that transit migration is an applicable scientific label (Düvell 2014, p. 231).

Migration shouldn't be understood as something strictly linear, with a clear beginning and end. Migration trajectories are dynamic as routes, stays, stages, destinations and plans change according to individual and structural factors (ibid). HERMAN (2006) also argues this in a more recent study on migrants who have moved to Europe and the roles of social networks during the mobility phase. However, what of the forced migrants and especially those asylum seekers who came to Austria during the last two years, as well as those who are still on their way? How can we frame and conceptualise their "mobility phase" and flight experiences? What roles do social networks and smugglers play?

UNHCR and Frontex publish information on geographical flight routes and current flows, journalists have presented us pictures of the routes, and forced migrants have shared their individual stories with the public; nonetheless, broader systematic comparisons and analyses of flight experiences are missing or rare. ${ }^{1}$ Using the concept of "transit migration", as well as key insights from forced migration studies (see part two of this paper), I analyse the 60 interviews from the pilot study in regard to transit and flight experiences. This includes an examination of the triggers for leaving, the different stages and stays during the flight, encounters with smugglers and the role of social networks (see part 3). My own ethnographical material from Izmir provides further insights into Turkey's central position within forced migration from the Middle East and Africa to Europe. The analysis will show that fleeing is not a linear process that leads refugees directly from their country of departure to their (current) country of destination. Instead - as DüvelL has already explained with the concept of transit migration - routes and plans change on the way. Furthermore, the material suggests that concepts like "country of origin" and "country of destination" are much more complex than they may seem in the first place.

\section{Transit Migration and Flight Routes}

In the first step, theoretical conceptions on transit migration and flight are presented in more detail. In the second step, I summarise the general flight routes in a geographical sense and explain how the 60 interviewees arrived in Austria. As forced migrants from

\footnotetext{
The large-scale research project MEDMIG led by the Centre for Trust, Peace and Social Relations at Coventry University will present their final report on the $3^{\text {rd }}$ November 2016. Having interviewed more than 500 refugees and migrants in Greece, Italy, Malta and Turkey, MEDMIG is definitely a pioneer project.
} 
three different countries took part in the pilot study, similarities or differences between experiences of Afghans, Syrians and Iraqis are outlined.

\subsection{Theoretical Conceptions of Transit and Forced Migration}

Scholars are polarised concerning whether the field of forced migration should be distinguished from general migration studies or not. Obviously both are highly connected and according to FidDIAN-QASMIYeH et al. it is best to use insights from both (FIDDIANQASMIYEH et al. 2014, p. 4f). The conception of transit migration, which is presented in the volume Transit Migration in Europe is situated within general migration studies, as it includes all kind of different forms of migrants (Düvell et al. 2014). As all forced migrants on their way to Austria are "transit migrants" at certain times, the concept helps to understand and analyse the flight, though it also excludes some aspects. Forced migration studies offer further insights into specific experiences connected to it and should be taken into consideration while discussing transit migration and flight.

The term 'transit migration' is used in different ways, though within the EU it is mostly connected with illegal border entries and migrants who intend to move to Europe (Collyer et al. 2014, p. 14f). This conception is not limited to the European region, but can be applied everywhere else. Definitions focusing on migrants' intentions tend to overlook the dynamics included in the process of fleeing. Structural and individual factors shape and change migratory routes and plans. The editors themselves have not developed their own definition, as it entails the risk of leaving ways of usage out. DüVELL describes transit migration in a retrospective manner as the simple fact that "migrants have transited a certain country (c) on their way from country (a) to country (b).”(DüVELl 2014, p. 232).

This transit or journey, though, is never unproblematic or simple and needs closer examination especially in regard to migrants' experiences in different countries on the route. For example, transit migrants may stay permanently in a country which was first thought as a transit country, or they may still move on after arriving in their "country of destination." Migrants may stay for a longer period of time in a "transit" country and then move on to the next country. Several larger themes are furthermore subsumed under the conception of transit migration, which need to be taken into consideration, such as humanitarian concerns, statistics, legal conditions, use of new technologies and the geopolitical significance of migration (COLLYER et al. 2014, p. 21f).

Wissink et al. (2013) offered an interesting case study on migrants in Turkey's transit hub, Izmir. Their case study exemplifies how migrants' intentions are determined by complex processes of conditions, opportunities, and experiences made en route. Different factors such as socio-political and economic conditions, socio-institutional environments, transnational networks, social class, gender, policies and legal frameworks influence transit migration. They highlight the problem of labelling migrants as transit 
migrants, since migrant flows are mixed and heterogenic. Several classifications, like labour, forced or voluntary migrants, asylum seekers and illegal migrants often apply at the same time for the same person. Furthermore, these classifications are in constant flux and are more like snapshots of specific stages during the transit. Others are stuck somewhere on the route - migrants wait in protracted situations especially at transit points to Europe like Libya, Egypt, Algeria, Morocco, Spain, Italy or Turkey. The borders of the Schengen zone, in Hungary, for example, and the British-French border are further bottlenecks within Europe.

Forced migration studies offer a broad range of insights into the various facets and dimensions of immobility and waiting, as well as protracted situations and liminal statuses of forced migrants in home, transit and host countries. Dawn CHATTY shows in Displacement and Dispossession in the Modern Middle East how forced migrants survive and manage to integrate within host societies (CHATTY 2010). Her ethnographic material, therefore, also outlines the struggles and experiences of being "en route." For example, one Armenian interviewee's father's state of "liminality" was overcome by religious charities and educational establishments, as well as the creation of new social networks (ibid. p. 282). СНАтту illustrated how difficult it is for forced migrants to reestablish a social structure, locality and community. This process requires a lot of time and hard work (CHAтTY 2010, p. 299).

As MALKKI stated, host countries perceive forced migrants as liminal and outside of the "national order of things," and therefore want to overcome this situation as soon as possible either by criticising them or placing them in refugee camps (СНАтту 2010, p. 296; MALKKI 1995). The majority of refugees now live outside of refugee camps in urban areas and/or are stuck in so-called protracted situations (MILNER 2014, p. 151). This means that refugees live in camps or other areas without any perspective of return or integration. It takes five years or more for them to achieve a durable solution. Thus "waiting" and also "immobility" become part of forced migrants" everyday life, as CONLON has showed in her case study on asylum seekers in Europe (ConLON 2011, p. 354f). How liminality, waiting and facing protracted situations are experienced by forced transit migrants on their flight will be discussed in the third part of this paper.

\subsection{Migratory Routes to Europe}

The "European Agency for the Management of Operational Cooperation at the External Borders of the Member States of the European Union" (better known as Frontex), which monitors illegal border crossings, defines seven migratory routes to Europe: Eastern border route (including Belarus, Moldova, Ukraine and Russia), Eastern Mediterranean route (from Turkey to Greece or Bulgaria), Western Balkan route (Macedonia, Serbia, Hungary, Croatia, Slovenia), Apulia and Calabria route, Central Mediterranean route (Libya and Egypt), Western Mediterranean route (Morocco and Spain) and Western African route (from Senegal, Mauritania and Morocco to the Canary 
Islands) (URL5). Similar differentiations are made by the UNHCR and the International Organization for Migration (URL6; URL7). During the last few years, migratory routes mainly concentrated on the Eastern Mediterranean and the Central Mediterranean route. Frontex estimates that around 885,000 people crossed the border between Turkey and Greece or Bulgaria within 2015, which is four times more than in 2014 (URL5). Most people choose to enter the EU by arriving by boat at one of the Greek islands near the Turkish coast. This large influx of migrants declined drastically during the end of March 2016 through the implementation of the Turkey-EU deal (URL8). Consequently the media has refocused on the Central Mediterranean route, where large ships overloaded with migrants try to reach Italy from Libya and Egypt. In 2016, 3,498 dead or missing migrants were counted so far, although the real number is expected to be much higher (ibid). The number of arrivals in Italy hasn't changed significantly in comparison to previous years, but stayed rather constant with 170,100 arrivals in 2014; 150,317 arrivals in 2015 and 130,000 until September 2016 (URL7; URL9). These statistics give insights into larger migration flows; however, it is impossible to get exact numbers of transit migrants (COLlyer et al. 2014, p. 23).

All of these migrants can be labelled as transit migrants and most of them as forced migrants too. The difficulty and problematic nature of labelling and categorising will be discussed in the next part of this paper. The forced migrants interviewed for the pilot study come from war-torn areas of Syria, Afghanistan and Iraq, and arrived in Austria in 2013, 2014 or 2015. Turkey played a key role for a large majority of them during their flight to Europe. Only a handful of the 60 interviewees didn't travel via Turkey: either they were Syrian UN refugees flying in directly from Lebanon or Afghans with valid or false papers flying via Dubai to Austria or another European country. All in all, however, nearly half of the Syrian interviewees came to Austria by plane with the UN, legal visas or due to family reunion mechanisms. In one case a Syrian interviewee arrived by plane with the aid of a smuggler. About a quarter of the Afghans questioned came the same way by plane with smugglers ${ }^{2}$ over Dubai or Turkey. Only three Iraqi interviewees arrived by plane, either through family reunion schemes, the UN or smugglers. The majority of all three groups fled to Europe over the Eastern Mediterranean and Western Balkan route. Thus, they either took a boat to the Greek islands or crossed the Turkish-Bulgarian border. Although the sample of the pilot study is not representative, the ethnographic material suggests that Syrians have easier access to legal ways of entering the EU through UN resettlement or family reunion. This fits into FidDiAN-QASMIYEH's description of Syrians as “ideal refugees" for Europe (FIDDIANQASMIYEH 2016, p. 459).

The duration of the actual transit varies from a few days - in the case of fleeing by airplane - to up to nine months. Most interviewees from all three groups named two weeks to three months for the actual flight. However, this duration of being en route doesn't include shorter or longer stays in between or preparation times. For example,

I will discuss the case of "smugglers" in section 3.3. 
coming to Europe through the UN or family reunion often took one-and-a-half to three years of waiting and preparing. It also doesn't reflect the original intentions or plans of refugees themselves. The following analysis of flight experiences from forced migrants in Austria and Turkey will provide a broader and more profound perspective of the "flight" as such.

\section{Flight Experiences of Refugees in Austria and Turkey}

This part presents the anthropological outcomes from the pilot study in Austria and my own research on refugees in Turkey. The following facets of the flight and transit are discussed: First, the aspect of actually leaving "home" and the initial steps of fleeing; second, the arrival and stay in Turkey as a pivotal moment; third, the role of smugglers, social networks and countries of destinations.

\subsection{Leaving "Home"}

The pilot study interviewees from Afghanistan, Syria and Iraq belong to different ethnicities, religions, social classes, gender and age groups. The majority though are young men, especially in the case of Afghanistan and Iraq. The majority of Syrian men and women are more highly educated and several of the Afghans and Iraqis worked in higher positions within the government. The eleven Kurdish and Arab households questioned for my MA thesis in Izmir consisted of parents with several children and often other extended family members. All of them fled from Syria to Turkey; two of the families were Palestinian refugees. Most of them came from the Northern part of Syria from cities like Aleppo, Kobane or Idlib. The men in the families had been working mostly as tradesmen such as painters, tailors or electricians. Compared to the Syrian refugees in Austria, they were less educated. There was only one family where the father (doctor) and son (law student) were higher educated.

In general, all interviewees from the pilot study and my own research lived under harsh conditions in countries shattered by war. In both studies the interviewees were explicitly asked for the actual triggers which led to their decision to flee. The large majority of the interviewees from all three groups of the pilot study named personal threats as decisive moments to flee. A few of the Syrians had been imprisoned (Sy4, Sy17, Sy18) and tortured, or threatened to be imprisoned or captured by other military groups (Sy9, Sy14, Sy16, Sy19). Christian Syrians felt personally threatened due to their religion and fled from direct attacks (Sy1, Sy7, Sy8, Sy9). The majority of the Afghan interviewees felt personally threatened as well. Several worked for foreign firms (A2, A3, A16, A19) or the government (A8, A9, A13), and were threatened by the Taliban or other military groups. Iraqi interviewees experienced similar situations. 
Several worked for the government or had family members who worked for the state (I1, I3, I18, I19); others had well-paid jobs and were pressured by the "Badr militia", ISIS or other military groups (I6, I7, I9, I12). Some of them were captured and tortured or had family members who were tortured and killed. For Yazidi Iraqis and a few others, religion was one of the most important reasons for their flight (I2, I5, I10, I16).

As further triggers, Syrian young men named the obligation to serve in the army (Sy3, Sy5, Sy15) or that the war conditions became unbearable as their houses were destroyed (Sy9, Sy16, Sy20). Most of the refugees interviewed in Turkey left on account of the latter. They either fled from bomb attacks or approaching troops, especially ISIS. Four of the eleven families first fled within Syria to another village. Only when these villages were also attacked did they move to Turkey. Another urgent reason for flight mentioned by several interviewees from all three pilot study groups, but especially Afghans, was personal problems within or between families. Young women, but also men, were threatened by other families or in-laws with death due to forbidden relationships (A5, A7, A10, A11, I14, I15).

Another important fact deriving from the Afghan case studies concerns the perception of the home country or country of origin. Nearly half of the Afghan interviewees spent most of their childhood and youth in Iran (A1, A5, A6, A7, A12, A17, A20).

"I was born in 1996, my mother said, Afghanistan was a warzone and so, one year later we fled to Iran" (Afghanistan 1, female, 20, place of origin: Kabul, 19-20).

"At a young age we fled from Afghanistan to Iran, at that time the Russians were in Afghanistan and religion didn't know borders, my father fled to Iran. There were lots of troubles on the way, my leg is damaged, I was a young boy at that time and I was dragged around and now my leg is like this. We stayed in Iran for 30 years" (Afghanistan 6, male, 33, Shiite, place of origin: Sari Pul, 10-13).

In one case, the interviewee was even born there as a child of refugees without any papers (A18):

"My family left Afghanistan because of the war and they fled to Iran, I was born in Iran, in Teheran, stayed there for 18 or 19 years [...] I had no papers, lived there illicitly in all those years, I lived there for 19 years illegally" (Afghanistan 18, male, Shiite, 18-25).

Afghan refugees in Iran live under harsh conditions and insecure legal situations, which led several of them to return back to Afghanistan (A1, A6, A18) or move on to Pakistan (A12). However, as life in Afghanistan was even more difficult, the interviewees decided to move on to Europe. Thus, eight of the twenty interviewees, who are defined within the pilot study and also within the Austrian legal system as Afghans according 
to their nationality, have spent the most part of their lives in Iran and hardly know Afghanistan itself.

The "country of origin" or "home country" in that sense doesn't seem to be that easy to name. Instead, Afghan interviewees have been refugees since their early childhood and then became asylum seekers in Europe. The same is true for those two Palestinian families in Turkey. Palestinians are the world's largest refugee group, with several generations born and raised in refugee camps in the Middle East (HANAFI 2014:586). These insights help to understand that refugees arriving in Europe may have already been refugees for most of their lives and define "home country" different to their country of birth or nationality.

The first stages of their flight led most of the interviewees to neighbouring countries like Lebanon, Turkey or Iran. Even those Syrian refugees who came with the UN had to flee first legally or illegally to Turkey or Lebanon. The same is necessary for family reunion procedures. Only Afghan interviewees who came to Europe directly by plane didn't pass through other neighbouring countries. "Iranian" Afghans, though, started their flight directly from Iran or by first going back to Afghanistan. While Afghans get connected with smugglers right at the beginning in Afghanistan or Iran (A2, A3, A6, A14), some Syrians and especially Iraqis came legally or without smugglers to Turkey, knowing that they would find smugglers there in order to continue (Sy1, Sy3, Sy14, I2, I10, I13, I17, I18, I19, I20).

"And so I came here like all the other young people. With a friend from Baghdad, we met in Hewler and from there we went to Ankara. From Ankara we took a bus to Izmir. We stayed there about one week until we could flee. We went to a coffee shop and waited there until we met a good smuggler, who knows the sea really well" (Iraq 17, male, Kurdish, place of origin: Tikrit, 32-37).

However, several Syrian refugees also paid to cross the border to Turkey and as one Armenian interviewee highlighted:

"Then we left from Aleppo to Turkey, the way was very difficult, all of it you should by money, you should by money, you were dealing with traffickers that they knew from which way they took you that you didn't face [...] I mean that to make the way secure. It is important that we arrived in Turkey." (Syria 8, female, 39 Armenian/Orthodox, place of origin: Aleppo, 20-23).

This quote outlines Turkey's specific position within the flight of forced migrants in the Middle East. The next part will focus on Turkey's role and the experiences of those refugees passing Turkey and those still staying there. 


\subsection{Turkey: Staying, Waiting or Leaving?}

Turkey has played a key role within migratory routes since the 1980s (ICDUYGU AND SERT 2014, p. 37). Forced migrants enter Turkey either with the intention to stay there or move on to Europe. The large majority of the interviewees from the pilot study intended to flee to Europe. However, not all of the refugees were able to find smugglers and depart within a few days to Greece. Instead, interviewees from all three groups stayed one, two or more months in Turkey and in a few cases several years. As the research material from Turkey shows, forced migrants who intend to move onto Europe may never reach Greece for several reasons. Financial resources are key factors, but not always decisive. Of course, during their flight forced migrants are not only held up in Turkey, but also in other countries like Lebanon, Iran, Greece, Macedonia or Hungary. This paper only focuses on Turkey, since I have additional ethnographic material and it is one of the most relevant bottlenecks to Europe. Furthermore, most of those interviewees, who lived for one year or longer in another country before fleeing to Europe, stayed in Turkey (Sy4, Sy9, Sy20, A17, A20, I13) - besides, of course, the cases of "Iranian" Afghans. Only in one case did an Iraqi woman suffering from cancer stay in Lebanon for one year before she received asylum through the UN (I12, 16-18). Half of the families questioned for the MA thesis have been in Turkey for two or three years and the other half between one and ten months.

The situation of forced migrants in Turkey is especially delicate, as Turkey has signed several readmission agreements for sending irregular migrants back (ICDUYGU AND SERT 2014, p. 51). Syrians are under a "temporary protection (TP) regulation," which came into force in 2014 and for which only Syrians are eligible:

"The new TP regulation sets out specific provisions for registration and documentation procedures; provides refugees with the right to a lawful stay in the country until safe return conditions are established in Syria, regulates the TP identification document, and grants access to social benefits and services such as health, education, and entry to the labour market." (ICDUYGU 2015, p. 9)

However, Syrian refugees in Turkey live in devastating conditions, especially in regard to housing and work conditions, health and the general lack of money (YILDIZ and UZGÖREN 2016, p. 203).

Furthermore, they are not completely safe from being sent back to the border region or even across the border, as human rights organisations and journalists have highlighted (URL10). Twenty-three refugee camps are located in Southeast Turkey, though the large majority of Syrian refugees are living outside of these camps, especially in urban areas in the Southeast, but also in larger cities like Istanbul and Izmir (3RP Refugee \& Resilience Plan 2016:4). The transit hub Izmir hosts forced migrants who came there directly to settle down temporarily or permanently, who want to move on to 
Europe and who are somehow stuck. Where and for how long migrants end up there is determined by several individual and structural factors mentioned at the beginning of the paper. Migrants move back and forth, and their intentions and possibilities change quickly according to social networks and socio-institutional factors, as Wissink et al. have argued (2013). The cases of the "Iranian" Afghans in the pilot study have also exemplified and highlighted furthermore that forced migrants' lives can be marked by circular and dynamic migration processes from an early age or even from birth onward and become an integral part of everyday life.

I will now present four case studies that illustrate the developments and stages of the flight of forced migrants who tried to find safe places for several years. All had intended to stay in Turkey and lived there for one or two years. The cases will show that the interviewees tried to establish themselves during this time, though due to several reasons were forced to move on in search of a more secure place. Three of them involved smugglers to move on and one case, Sy9, received asylum from the UN.

Sy4, a 53-year-old Muslim woman from Damascus, was active within several civil organisations and media groups which documented human rights abuses (Sy4:289-290). She was imprisoned and tortured for seven months. After her brother was killed in prison and she felt threatened again, she decided to leave Syria. With the help of a smuggler she crossed the border to Lebanon. The Democratic Party in Turkey had invited her months before to a conference and therefore she could enter Turkey legally from Beirut. So she participated in the conference organised by the Democratic Party and told them that she couldn't go back. They offered her to work with them for two months (Sy4:303-305). After that she was able to work with the interim government. However, this became problematic for her and she didn't feel secure in Turkey. So after staying there for a year and a half she decided to move on to Europe, since there was no other possibility. Thus, together with her family, who followed her to Turkey later on, she searched a smuggler, went to Izmir and from there by boat to Greece.

Sy9, a 37-year-old Yazidi woman from Aleppo, left her house together with her husband and her five daughters when ISIS fighters came to their house for the first time. They left immediately with the woman's brother in-law and went to their relatives in Afrin (Sy9:15-21). One month later their house in Aleppo was hit by a bomb and everything was destroyed. They stayed in Afrin for four months, but as there was no work and no possibility to survive, they moved on to Turkey. Sy9's husband had been working in a government-run company before and she herself was a seamstress. Her husband was caught while walking on the streets during the demonstrations. He was imprisoned and beaten badly. His suffered head injuries from the torture and has had epileptic fits ever since, which makes it impossible for him to work (Sy9:65-69). Life in Turkey was very hard for them, as Sy9 was the only one working in the family and at that time she was also in an early stage of pregnancy. Her sister, who had also fled to Turkey, brought her to ASAM, a national NGO working with the UNHCR. She originally asked them to help her get an abortion. ASAM checked the family's living conditions and as 
the family was extremely vulnerable, they suggested an application for resettlement with the UNHCR (Sy9:35-46). All-in-all they stayed in Turkey for two years until they received a positive decision and left by airplane with the UN to Austria.

A20 is 24-year-old (Sunni Muslim) whose family fled from Afghanistan to Iran when he was seven years old (A20: 6-7). He had no right to education and, as an Afghan, was discriminated against. Since he was often captured and had to pay to get released, he left Iran as a young man and moved to Turkey. He wanted to stay there and find work. For one year he worked in the textile branch and he wanted to settle down. However, as he realised that he wouldn't be able receive asylum or any other official papers, he moved on to Greece with a smuggler (A20: 23-26). In Greece he was arrested and spent six months in prison. He stayed another two-and-a-half years in Greece until he had the opportunity to move on to Italy. A20 originally planned to go to Germany, though when he left the lorry he was hiding in, he didn't know where he was. He learned that he was in Salzburg, Austria from a girl he approached in the supermarket (A20: 31-37). Two policemen approached him there and told him to stay in Austria. He accepted that and moved to Traiskirchen.

I13, a 22-year-old Sunni Kurd from Kirkuk, was writing for newspapers. His family had to flee their hometown several times. They fled twice to Iran for several months and once in 2003 within Iraq during bomb attacks by the US (I13: 244-247). Similar to those Afghans fleeing to Iran and also the case of Palestinians in general, forced migration and dispossession is part of collective memory and life for Kurds in the Middle East. I13 moved to Turkey because he didn't see any prospects for himself in Iraq. He lived there for one year and worked; however, he had problems finding and keeping jobs due to his Kurdish background (I13: 20-25). So he moved back to Iraq, where the situation had worsened; ISIS had started to influence the area and he felt threatened. This led him to move to Turkey in search for a smuggler to get to Greece.

Thus, in all of the cases above, people were working in their home countries before, but were forced to leave due to conflict and personal threats. They tried to settle down in Turkey and found some kind of semi-legal jobs. However, life in Turkey was still marked by insecurity and uncertainties due to legal conditions, threats and the inability to make a living for themselves and their families. These cases show that forced migration and economic drivers for migration are interrelated and complexly connected. A20 and I13 were living in liminal situations without papers or the prospect of being integrated into Turkish society and structures. Sy4 had connections to political parties that helped her gain a foothold within Turkish society; however, the political situation didn't allow her to stay. Sy9's story outlines one of the (few) cases of resettlement taking place from Turkey to other safe third states. As the narrative explains, Sy9 was connected to ASAM through her sister. She had no knowledge about the possibility of applying for asylum and the opportunity came about only by chance. Other interviewees from the pilot study similarly experienced this and accounts from forced migrants in Izmir confirmed it too. As I argue within my thesis, local and national organizations like ASAM - responsible 
for registrations of the UNHCR - depend on informal networks of relatives, neighbours and others to get in touch with forced migrants and vice versa. Regarding the large number of forced migrants in Turkey however, it is clear that local NGOs and other organisations can only reach a small part of them.

Four of the eleven families interviewed for my master's thesis want to return to Syria as soon as the conditions allow it.

"We want to go back, if I had the option, I would go there right now. And my sister went back, she is fine there, there is no war." (P32: Syrian, female, 40, place of origin: Kobane, 179).

In two cases the elderly family members already returned, since life was too hard for them in Turkey. In another case the brother of one interviewee, a father of five children, went back to Kobane to fight against ISIS and was killed shortly afterwards. Five of the eleven families interviewed in Izmir intended to move on to Europe when they came to Turkey. Some of them have been living in Turkey for two or three years already. For example, one family went to Urfa three years ago and the women collected trash in order to make a living (P30: 87-88). They had hoped for a better life, but the conditions were very hard for them. So they saved their money for nearly three years and went to Izmir. They arrived twenty-two days before we interviewed them in Basmane. In Basmane they made a connection with a man who promised to transfer them to Greece. They gave him all of their savings; however after they paid the man, he attacked and threatened them - they were able to escape, but were cheated out of 3000 euros (P30: 151-152). Now the family is sleeping on the streets in Basmane without anything.

Another family told a similar story, although they didn't pay a fake smuggler, they lost their money on the flight (P31: 138-142). They were in Basmane for one week, sleeping outside as well. They had paid 300 dollars each to pass the Syrian-Turkish border (P31: 41-47). They still had 1500 dollars left. While crossing the border they heard that Turkish policemen were coming, so they had to run and leave their bags containing the money behind. A third family who has lived in Turkey for three years now managed to reach Greece once, but they were sent back (P44: 79-81). Since then they have been living in Izmir in a flat together with twelve people (extended family members). As the man was injured during the war, he can't work, so the women of the family roll cigarettes and collect trash to make money (P44: 33-35). They think that living in Turkey is okay, but they would still like to leave. Thus, all of the families lack the money needed to pay smugglers and therefore have no other choice than to stay in Izmir or move to another location in Turkey. Still, some of them are convinced that the flight to Europe is the only way; as one man states: "I prefer to die in the sea, there is no other option for me" (P31: 173). However, so far they have been condemned to immobility and remain in a "waiting" position. 
All of the different cases presented in this part show that forced migrants never know where they end up. Sy4, Sy9, A20 and I13 wanted to stay in Turkey, but left to Europe for different reasons and managed to arrive in Austria. The three Syrian families mentioned above all wanted to move to Europe, but simply had bad luck, lost their money and have been forced to stay in Turkey - at least as long as it takes to save the money needed for the transfer. These cases show how difficult it is to label individuals as transit migrants. They wanted to transit, but didn't succeed. Even if they plan to move on to Europe, they are stuck in Turkey for an unknown time. Some of them may never reach this goal, so when do they stop being transit migrants? Thus, as mentioned before, the concept of transit migration describes a general migratory phenomenon, not a specific type of migrant.

The families living on the streets are in danger of being taken back to the border, since the police organises regular raids. Thus, finding a flat and a job are the most important things to overcome this liminal state. However, it will take much more time to create a new locality and structure which - as outlined before in relation to СнАтTY - is hard work (Снатту 2010, p. 299). Considering the family who have already spent three years in Turkey and then tried to move on to Europe, losing everything they had, it is clear that they have to start all over again. The ethnographic material from Izmir has revealed that informal forms of civil society like neighbourhood networks, Syrian solidarity groups and Facebook groups are important elements that help forced migrants to cope and manage their new life situations. These informal groups support refugees in finding houses, furniture and material; they help with translations in hospitals and at work and, last but not least, provide useful information on how to deal with basic problems and issues in Turkey. As already mentioned above, they also inform them about possibilities to get further help, for example, from NGOs like ASAM. All these informal groups as well as NGOs, other organisations and religious institutions - which could all be grouped under the term civil society - contribute to the creation of a new locality and social structure. In addition, forced migrants are part of transnational networks, as all of them remain connected with their home country and most of them have family members, relatives or friends who already live in another part of the world. The next part of my paper focuses on these social and transnational networks and their role within the flight in addition to the role of smugglers.

\subsection{Smugglers, Networks and the Countries of Destinations}

The majority of the interviewees from the pilot study came to Austria illegally, though not all parts of the flight were illicit. As mentioned before, several of them came to Turkey or Dubai legally. Consequently, all of them needed the services of smugglers for most parts of their flight. Ahmet ICDUYGu has explained that the smuggling system within the Eastern Mediterranean route is not a centralised, all-encompassing organisation like other criminal organizations (ICDUYGU 2004, p. 311). Instead, it consists 
of small, self-operating units specialised in narrow fields and portions of the flight. Migrants are simply handed over to the next smuggler. This fits the descriptions from interviewees coming the same way, though those Afghans coming by plane to Europe were accompanied by their smugglers during the entire process. ICDUYGU's research has furthermore shown that social relations between migrants and smugglers are often based on mutual understanding and trust (ibid, p. 311f). However, the exploitative nature of the relationship remains present throughout the flight. As the documentaries named earlier have shown and the interviewees from the pilot study have mentioned, smugglers were often armed and made use of their weapons to threaten them. Interviewees also mentioned that they lied to them, gave them wrong information and used violence during the transfer, not to mention the exhausting, dangerous and extremely hard means of transportation.

"They told us not to make a single noise, I even had to give my little daughter sleepinducing medication, sleep-inducing medication, she was unconscious for one and a half days, she was just unconscious. They told me, I should give her sleep-inducing medication so no one could hear her and they closed the door behind us" (Afghanistan 6, female, 27, Shiite, place of origin: Mazare-Sharif, Iran, 111-114).

One Syrian interviewee explained that you have to pay again and again for each part (Sy3: 178-198). Those who don't have any money left try to proceed on their own with mobile phones and GPS, but it's too difficult because they don't know where police and military are located and are likely to get arrested. Some of the forced migrants paid between 10,000 and 15,000 dollars (for example, Sy5, A9, I18). They were also forced to pay extra for food and accommodation during the flight. For instance, one Iraqi interviewee had to pay $€ 60$ per night to stay at a hotel with the smugglers (I3: $97-$ 98). Policemen also had to be paid during the flight, for example, in Turkey, Macedonia or Serbia (I4: 34-42; I17: 59-61). During the flight through the Balkans, a Syrian interviewee was caught in Hungary and sent back to Serbia:

"They return us back to Serbia, the Serbians took us to prison, they gave papers, [kharta] try another time they said, God be with you, the Serbian police, of course we paid 60 or 80 euro for everyone to the police." (Syria 5, male, 30, Sunni, place of origin: Damascus, 320-322).

Thus, certain corrupt policemen also benefit from the "refugee industry" besides smugglers and businessmen, who sell products and hotel rooms to forced migrants (URL11). The quote furthermore shows that forced migrants face setbacks, as they are arrested by police forces and imprisoned or sent back. Several Iraqis, as well as others, experienced one or more failed attempts to cross the Aegean Sea because the boat sank. 
In most cases, the contact with smugglers was established at places where smugglers are known to be, such as Basmane in Izmir. However, a few of the interviewees had friends or relatives living in Austria or Turkey who helped them organise the flight (Sy7, Sy8, I7, I19). For example, a 22-year-old Iraqi called his cousin in Austria and asked him if he could help, so the cousin sent him the phone number of one smuggler in Turkey (I7: 52-58). Remarkably, in the Afghan group at least six of the twenty interviewees mentioned that family members or relatives arranged the smuggling (A2, A3, A10, A11, A14, A17) and, in one case, a friend (A5).

"My uncle (the brother of my mother) knew about the whole situation. He talked to people, I don't know to whom, he managed everything, he just told me to come to a certain place at a certain day, where he could hand me over to the person" (Afghanistan 2, male, 23, place of origin: Laghman, 25-28).

Thus, most of them, especially those coming by plane, had no influence or any idea of where they would go or end up, as it was planned and decided by the smugglers and family members. Syrian and Iraqi refugees also experienced being completely lost on the route and not knowing where they were. In several cases the interviewees arrived in Austria without knowing it, as the story of A20 has already demonstrated in the previous part of this paper. I16 from Iraq arrived at the Vienna airport and only learnt from a taxi driver outside that he was in Austria (I16: 25-28).

Austria had already been an important transit country for forced migrants before the great influx in 2015. However, the interviewees arrived and stayed in Austria for different reasons. As mentioned, several Afghans were brought to Austria with their smugglers without knowing it or agreeing to that. In the few cases of family reunion and $\mathrm{UN}$ resettlement, it is clear that refugees entered Austria in an official manner. But what about the influence of transnational networks? As mentioned at the beginning, social networks of kinship or friends are seen as important, decisive factors for migrants' countries of destinations (CRAWLEY et al. 2016, p. 7). Over two-thirds of the pilot study group mentioned having relatives and/or friends in Europe and Northern America: 18 Syrians, 13 Iraqis and 11 Afghans have transnational ties. However, the majority of these relatives and friends don't live in Austria, but in Germany, Sweden, Great Britain, Denmark and several other countries. The number of those forced migrants who only have relatives or friends in Austria is remarkably lower: 5 Syrians, 3 Afghans and 3 Iraqis had exclusively social ties to Austria. Thus, it cannot be stated per se that forced migrants move to those countries where their relatives or friends live.

However, some of the interviewees explicitly named the presence of family members or friends as reasons for coming to Austria, especially Syrians (Sy4, Sy10, Sy15, Sy14, Sy17, A18, I7, I11). 
"I have my nephew, the son of my sister [...] he is in Germany. I decided to stay in Austria, because I have friends here. [...] and I have talked to them, Austria is good and calm and Vienna is, erm, it's not like the others, it is good for refugees, they told me. Yes, and I came" (Syrian 10, male, 45, Muslim, place of origin: Idlib, 176-188).

In two cases the interviewees arrived in Germany and France and moved back to Austria, since they wished to stay with their family (Sy4, Sy17). In a few other cases the interviewees, while en route, were persuaded by friends in Austria to come there, although they had planned to move to Germany or Denmark (Sy12, A3, I13). A few other interviewees, especially Iraqis, had intended to move to Germany, France, Belgium or Great Britain; however they were either sent back to Austria, got stopped by the police or were so exhausted that they decided to stay (A20, I3, I9, I14, I17, I20).

"I didn't plan to stay in Austria. I wanted to go somewhere else. [...] But as I arrived in Austria, I couldn't move on. I was totally tired and exhausted. I was really at the end of my tether. I couldn't take one more step. I stayed in Vienna for 3 days and I liked it straight away." (Iraq 9, male, 23, Sunni/Shiite, place of origin: Bagdad, 34-45).

Thus, forced migrants' trajectories are highly heterogenic, dynamic and to a certain extent unpredictable, as DüvELL also concluded within Transit Migration to Europe (DüVELL 2014, p. 233).

\section{Conclusion}

Transit migration helps understand the phenomenon of the "flight" as a nonlinear, dynamic process in which plans and routes change according to individual and structural factors. The narratives of the pilot study and forced migrants in Izmir have shown this in various ways. Financial resources, policies and socio-institutional embeddedness influence them, but so does luck. Forced migrants and refugees remain within a liminal state until they manage to integrate or create a new locality, social structure and community. This is hard work and takes a lot of time. The material from Izmir has shown that informal social networks from neighbours, Syrian solidarity and social media groups help forced migrants cope and manage their first steps in the new host society. This can be described as civil society, as it incorporates formal institutions like local NGOs, associations and religious institutions.

The majority of the 60 interviewees from the pilot study came via Turkey and the Eastern Mediterranean and Western Balkan route to Austria. Only a small number of the interviewees came to Austria in a legal way, with resettlement by the UN or family reunion regulations. However, even those who arrived illegally in Austria travelled parts 
of their flight legally; especially the travel to Turkey was often done legally. Looking at the forced migrants' backgrounds, the Afghan case studies show that the country of origin and the home country are not easily definable categories. Nearly half of them spent their childhood and youth as Afghan refugees in Iran. Thus, being a refugee has always been an integral part of everyday life. This is similar in regard to Palestinian or Kurdish refugees from the Middle East.

Only in a few cases did the flight happen within two or three weeks; longer stays in Turkey, Greece or Macedonia were frequently necessary. Turkey's specific role as a bottleneck to Europe is still central for forced migrants. They either succeed in reaching the European Union and enter the asylum system, or remain within a liminal phase within Turkey.

The refugees interviewed in Vienna arrived in Austria for different reasons. In seven cases the flight for Afghan refugees was organised by family members or friends. In some Syrian and Iraqi cases as well the forced migrants didn't know where the smugglers left them. In other cases, social networks are often highlighted as decisive factors for countries of destinations. However, two-thirds of all interviewees have transnational ties to relatives or friends in Europe or Northern America, though most of them don't live in Austria. Therefore, social ties are not necessarily the most relevant aspects. Remarkably, nearly half of the Iraqi interviewees had planned to move to other places than Austria but, due to various reasons, stayed there.

The narratives of the pilot study show that forced migrants' trajectories are highly heterogenic, dynamic and unpredictable. Further large-scale quantitative and qualitative studies like MEDMIG are definitely needed and will bring further insights into forced migrants' flight - especially since the EU-Turkey deal and increasing political uncertainties within Turkey. The situation for forced migrants has become more tense and their future has become even more insecure within a region where stabilisation seems to remain out of reach for a very long time.

\section{References}

3RP Refugee \& Resilience Plan (2016), Turkey: Regional Refugee \& Resilience Plan 20162017 - In response to the Syria Crisis. Retrieved from <http:/www.3rpsyriacrisis.org/wpcontent/uploads/2016/01/Turkey-2016-Regional-Refugee-Resilience-Plan.pdf>

BAuER W. (2014), Über das Meer - Mit Syrern auf der Flucht nach Europa. Berlin, edition suhrkamp.

Brettell C.B., \& Hollifield, J.F. (eds.). (2015), Theorizing Migration in Anthropology. Cultural, Social, and Phenomenological Dimensions of Movement. In: Migration Theory: Talking Across Disciplines (pp. 147-197). New York, London: Routledge.

Chatтy D. (2010). Displacement and Dispossession in the Modern Middle East. New York: Cambridge University Press. 
Collyer M., Düvell F., de HaAs H. \& Molodikova I. (2014), Introduction. Transit Migrations and European Spaces. In: Düvell F., I. Molodikova I. \& Collyer M. (eds.), Transit Migration in Europe, pp. 13-36. Amsterdam, Amsterdam University Press.

Conlon D. (2011), Waiting: feminist perspectives on the spacings/timings of migrant (im)mobility. Gender, Place \& Culture. Retrieved from <http://www.tandfonline.com/doi/abs/10.1080/0 966369X.2011.566320>

Crawley H., Düvell F., Jones K. \& Skleparis D. (2016), Understanding the dynamics of migration to Greece and the EU: drivers, decisions and destinations. (MEDMIG Research Brief No. 2), Retrieved from <http://www.medmig.info/research-brief-02-Understandingthe-dynamics-of-migration-to-Greece-and-the-EU.pdf>

Daniel S. (2008), Les routes clandestines: l'Afrique des immigrés et des passeurs. Paris, Hachette.

Düvell F. (2014). Transit Migration in the European Migration Spaces. Politics, Determinants and Dynamics. In: Düvell F., Molodikova I., \& Collyer M. (eds.), Transit Migration in Europe, pp. 209-236,. Amsterdam, Amsterdam University Press.

Düvell F., Molodikova I. \& Collyer M. (eds.). (2014), Transit Migration in Europe. Amsterdam, Amsterdam University Press.

Fiddian-QAsmiyen E. (2016), Representations of Displacement from the Middle East and North Africa. Public Culture, 28 (3 80), pp. 457-473. <https://doi.org/10.1215/089923633511586>

Fiddian-QAsmiyeh E., Loescher G\& Long K. (eds.) (2014), The Oxford Handbook of Refugee and Forced Migration Studies. Oxford, Oxford University Press.

Fiddian-Qasmiyeh E., Loescher G., Long K. \& Sigona N. (2014), Introduction: Refugee and Forced Migration Studies in Transition. In E. Fiddian-QAsmiYen E. Loescher G. \& Long K. (eds.), The Oxford Handbook of Refugee and Forced Migration Studies, pp. 1-22. Oxford, Oxford University Press.

Hanafi S. (2014), Forced Migration in the Middle East and North Africa. In: E. Fiddian-QASMiYeH E., Loescher, G. \& Long K. (eds.), The Oxford Handbook of Refugee and Forced Migration Studies, pp. 585-598. Oxford, Oxford University Press.

Herman E. (2006), Migration as a Family Business: The Role of Personal Networks in the Mobility Phase of Migration. International Migration, 44(4), pp. 191-230. <https://doi. org/10.1111/j.1468-2435.2006.00384.x>

ICDUYGu A. (2004), Transborder Crime between Turkey and Greece: Human Smuggling and its ? welche Regional Consequences. 4, 2, pp. 294-314.

ICDUYGu A. (2015), Syrian Refugees in Turkey: The Long Road Ahead. Washington DC: Migration Policy Institute. Retrieved from <http://labs.ozyegin.edu.tr/ozumigs/files/2015/05/TCMProtection-Syria.compressed.pdf $>$

ICDUYGu A. \& SERT D. (2014), Migrants' Uncertainties versus the State's Insecurities. Transit Migration in Turkey. In: Düvell F., Molodikova I. \& Collyer M. (eds.), Transit Migration in Europe, pp. 37-54. Amsterdam, Amsterdam University Press.

Kallius A., Monterescu D., \& RaJaram, P.K. (2016), Immobilizing mobility: Border ethnography, illiberal democracy, and the politics of the "refugee crisis" in Hungary. American Ethnologist, 43(1), pp. 25-37. <https://doi.org/10.1111/>

MaLKKi L.H. (1995), Refugees and Exile: From "Refugee Studies" to the National Order of Things. Annual Review of Anthropology, 24, pp. 495-523. 
Milner J. (2014)., Protracted Refugee Situations. In: E. Fiddian-QASmiyeh E., Loescher G. \& Long K. (eds.), The Oxford Handbook of Refugee and Forced Migration Studies, pp. 151162. Oxford, Oxford University Press.

Turner V. (1969), The Ritual Process: Structure and Anti-Structure. Chicago, Aldine Publishing.

Wissink M., Düvell, F. \& EerdewiJk A. van. (2013). Dynamic Migration Intentions and the Impact of Socio-Institutional Environments: A Transit Migration Hub in Turkey. Journal of Ethnic and Migration Studies. Retrieved from $<$ http://www.tandfonline.com/doi/full/10.10 80/1369183X.2013.778026>

YILDIZ A. \& UzGÖREN E. (2016), Limits to temporary protection: non-camp Syrian refugees in İzmir, Turkey. Southeast European and Black Sea Studies, 16(2), pp. 195-211. <https://doi. org/10.1080/14683857.2016.1165492>

URL1: <http://www.bbc.co.uk/programmes/b07ky7sn>

URL2: <http://www1.wdr.de/mediathek/video/sendungen/wdr-dok/video-my-escape--meineflucht-100.html>

URL3: <http://www.medmig.info/>

URL4: <http://journals.plos.org/plosone/article?id=10.1371/journal.pone.0163481>

URL5: <http://frontex.europa.eu/trends-and-routes/migratory-routes-map/>

URL6: <http://data.unhcr.org/mediterranean/regional.php>

URL7: > <ttp://www.iom.int/news/migrant-arrivals-sea-italy-top-170000-2014>

URL8: <http://reporting.unhcr.org/node/2544\#_ga=1.187373096.1671764409.1474874892>

URL9: $\quad<$ http://www.iom.int/news/irregular-migrant-refugee-arrivals-europe-top-one-million2015-iom>

URL10: <https://www.amnesty.org/en/latest/news/2015/12/turkey-eu-refugees-detentiondeportation/>

URL11: <http://muftah.org/the-refugee-industry-in-turkey/> 